\title{
Jesus, the Apostle and High Priest of Our Confession. Audience-Oriented Criticism of Heb 3:1-6
}

\author{
PIOTR BLAJER \\ Studium Biblicum Franciscanum, Jerusalem \\ pblajer@antonianum.eu \\ ORCID: 0000-0001-8835-9357
}

\begin{abstract}
Hebrews 3:1-6 is one of the most intriguing passages of the letter. It catches the attention of who reads or hears the letter for several reasons: one of which is the way the author presents Jesus Christ. It establishes a comparison between Moses and Christ in order to demonstrate Christ's superiority as the high priest and apostle. It is the only passage in the New Testament where Jesus is presented as an apostle. The reader-oriented research points out to the way the author addresses the audience of his letter and how he manages to catch their attention and present their present status. Those who accept Christ's mission as the apostle are sanctified and can be considered the house of God governed by Christ.
\end{abstract}

KeYwords: Hebrews, Apostle, Jesus, Moses, reader-oriented research

$\mathrm{H}$ ebrews 3:1-6 is one of the passages that catches the attention of the audience for several reasons. First of all, the author compares Moses to Christ in order to demonstrate Christ's superiority as the high priest and apostle, thus making it the only passage in the New Testament where Jesus is presented as an apostle. Second, in such a short passage, the author addresses the audience in several different ways. He calls them brothers, partners of heavenly calling and house of God. The author not only speaks to the audience and exhorts them, but he is also part of this audience. In this article, I employ audience-response criticism, a method that focuses on how the implied audience responds to the text as it progresses. ${ }^{1}$ This approach enables to demonstrate how the author develops the idea of Christ's superiority and how the audience react. ${ }^{2}$

1 The methodology of this paper employs the tools of audience-response criticism, better known as reader-response or reader-oriented criticism/theory. This method focuses on how the "audience" responds to the author's rhetorical argument in the text as the letter progresses. The audience-oriented method, understands the "audience" as a historical group of addressees of whom the author is cognizant as he/she writes. Thus, this is not a group that is historically reconstructed or created by the reader; rather, the audience is understood as the group of addressees implied within the text, and thus may be referred to as the "implied," "textual," "intended," or "ideal" audience. Biblical scholars, especially in the United States, have noted that in addition to the diligent examination of the text to discuss the theological ideas in the writings, the part played by the read- 


\section{Hebrews 3:1-6 in the Previous Biblical Studies}

Hebrews 3:1-6 has been at the center of scholarly debate for quite some time. Many questions have been raised concerning this passage, several solutions have been proposed and yet more might ensue. Some questions pertain to the rationale of the comparison between Moses and Jesus. Did the author include this part because he was writing to a community where Moses was held in great esteem, or was it included to demonstrate Jesus' superiority over Moses, the lawgiver of the first covenant? ${ }^{3}$ Apart from the function of Moses in this passage, scholars turn their attention to the out of the ordinary use of the title $\dot{\alpha} \pi$ ó $\sigma \tau 0 \lambda \mathrm{o} \varsigma^{4}$ applied to Jesus in 3:1, the exact meaning and function of o $\mu o \lambda o \gamma i \alpha^{5}$ in $3: 1$ and the accurate

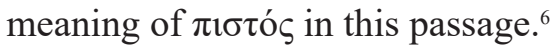

The above-mentioned problems are not the only questions that interest scholars. In fact, one of the longest debates pertains to the structure of the passage.

ers of the books is also crucial. In fact, the words are lifeless until the implied audience reading or hearing begins to ask questions. In other words, the audience-response criticism focuses on the act of reading and on the activity of readers as they read. For examples of such method used to read the biblical texts see E.V. McKnight, Postmodern Use of the Bible. The Emergence of ReaderOriented Criticism (Nashville, TN: Abingdon 1988); R.M. Fowler, Let the Reader Understand. Reader-Response Criticism and the Gospel of Mark (Minneapolis, MN: Fortress 1991); W.C CarterJ.P. Hail, Matthew's Parables. Audience-Oriented Perspectives (CBQMS 30; Washington, D.C.: Catholic Biblical Association of America 1998) 12-13; P.J. Rabinowitz, "Whirl Without End: Audience-Oriented Criticism," Contemporary Literary Theory (ed. G.D. Atkins) (Amherst, MA: University of Massachusetts Press 1989) 81-100; J.P. Tompkins, Reader-Response Criticism. From Formalism to Post-Structuralism (Baltimore, MD: Johns Hopkins University 1980); M.A. Powell, What is Narrative Criticism? (Minneapolis, MN: Fortress 1990).

2 Here and throughout the paper I take the noun "audience" as a collective noun. The plural form corresponds better to the Greek text where plural nouns are used for the audience.

3 A short presentation of this discussion along with the importance of Moses in Judaism can be found in P. Ellingworth, The Epistle to the Hebrews. A Commentary on the Greek Text (NIGTC; Grand Rapids, MI: Eerdmans 1993) 194-197; K.L. Schenck, Understanding the Book of Hebrews. The Story Behind the Sermon (Louisville, KY: Westminster John Knox 2003) 60; B.R. Scott, "Jesus' Superiority over Moses in Hebrews 3:1-6," BSac 155 (1998) 201-210.

4 Commentators suggest that the title is used in a general sense of an emissary. J. Casey, Hebrews (NTM 18; Wilmington: Glazier 1980) 14; C.R. Koester, Hebrews. A New Translation with Introduction and Commentary (AB 36; New York: Doubleday 2001) 243; W.L. Lane, Hebrews 1-8

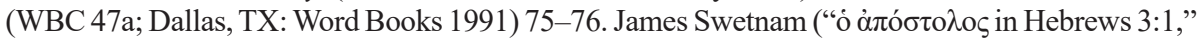
Bib 89 [2008] 262) takes it as a reference to the risen Jesus in Heb 2:12 who has been "sent" by God to reveal God's name as Moses was sent to reveal God's name.

5 A short presentation of the discussion Lane, Hebrews 1-8, 75; N. Casalini, Agli Ebrei. Discorso di esortazione (SBFA 34; Jerusalem: Franciscan Printing Press 1992) 137-138; J.W. Thompson, Hebrews (Paideia Commentaries on the New Testament; Grand Rapids, MI: Baker 2008) 79-80.

6 Franco Manzi ("La Figura di Mosè nell'epistola agli Ebrei e nel Dialogo con Trifone," RivB 51 [2003] 7-8) suggests that the adjective $\pi \_$ 
Some commentators point out that the passage refers to what has been said so far, ${ }^{7}$ while others prefer to take it as an introduction to what follows. ${ }^{8}$

The commentators agree that the passage starts in 3:1 and ends in 3:6. The conjunctions ö $\theta \varepsilon v$ and $\delta$ tó begin two new sections. ${ }^{9}$ In the same way, the name Jesus in 3:1 is parallel to Christ in 3:6 and marks the beginning and the end of the passage. This universal agreement seems to end at this very stage. Scholars disagree on the precise nature of the passage. Consequently, they outline the passage in different ways. For example, Albert Vanhoye divides the passage in four parts; an introduction and the comparison between Moses and Jesus (3:1-2) is followed by an affirmation that Jesus is superior to Moses (3:3), and a detailed exposition of the rapport (3:4-6a) between the two is followed by an exhortation $(3: 6 \mathrm{~b}) .^{10}$ Harold W. Attridge distinguishes two main parts in the passage; an introductory verse (3:1) is followed by the first part (3:2-3) and then the second one (3:5-6). The center of the passage (3:4) is understood as a parenthesis. ${ }^{11}$ Nello Casalini divides the passage in two parts; the initial invitation to look at Jesus, as high priest and apostle (3:1-2), is followed by a short yet eloquent exposition of Jesus' superiority over Moses (3:3-6). ${ }^{12}$ Finally, Erich Grässer divides the passage in the following way; an initial invitation to look at Jesus (3:1) is followed by the reference to Moses (3:2) whereas Midrash on Num 12:7 (3:3-6a) is followed by an exhortation $(3: 6 b) .{ }^{13}$

\section{The Disposition of the Audience and their Response to the Content of the Letter}

Hebrews 3:1-6 is a central part in the first series of eleven units $1: 1-5: 10 .{ }^{14}$ So far, the audience heard five units that will help them to understand the message proclaimed in 3:1-6. A solemn introduction in 1:1-4 informed the audience that

7 James Swetnam ("The Structure of Hebrews 1:1-3:6," MelT 43 [1992] 58) notes that the structure of the passage is far from being the easiest to confront. He believes that 3:1-6 is a key passage for the first part of the letter.

8 Peter E. Enns ("Creation and Re-Creation: Psalm 95 and its Interpretation in Hebrews 3:1-4:13," WTJ 55 [1993] 269) argues that Heb 3:1-6 "serves as an introduction to the writer's exegesis of Psalm 95 which begins in verse 7."

$9 \quad$ E. Grässer, An die Hebräer: Hebr 1-6 (EKKNT 17/1; Zürich: Benziger 1990) 157.

10 A. Vanhoye, La structure littéraire de L'Épitre Aux Hébreux (Paris: Desclée De Brouwer 1976) 89.

11 H.W. Attridge, The Epistle to the Hebrews (Hermeneia; Philadelphia, PA: Fortress 1989) 104.

12 Casalini, Agli Ebrei, 136.

13 Grässer, An die Hebräer, 157; E. Grässer, "Mose Und Jesus: Zur Auslegung von Hebr 3:1-6," ZNW 75 (1984) 2-23.

14 I follow the division of the letter in three parts proposed by John Paul Heil (Hebrews. Chiastic Structures and Audience Response [CBQMS 46; Washington, D.C.: Catholic Biblical Association 2010] 12-13). 
God spoke in many different ways but now, in the final days, he chose to speak in the person of his Son.

Having established the superiority of the message uttered through the Son, the author moved on to describe the superiority of Jesus over the angels (1:5-14). This superiority was proven by means of seven quotations taken from the OT. These skillfully chosen texts demonstrated that the Son was begotten by the Father 1:5a (cf. Ps 2:7), and therefore he was the only one who could rightly be called the Son 1:5b (cf. 2 Sam 7:14). The angels worshiped Jesus as he entered into the world 1:6 (cf. Ps 97:7) and were his servants 1:7 (cf. Ps 104:4). The sonship of Jesus not only made him superior to the angels, it also secured him a throne and dominion over the whole earth. At this point, the audience were told that the Son's dominion would be everlasting 1:8 (cf. Ps 45:7) because he loved justice and hated iniquity. He was anointed with the oil of gladness above all his fellows 1:9 (cf. Ps 45:7). Jesus' superiority over the angels derived from his presence at the moment of creation of the world 1:10-12 (cf. Ps 102:25-27), as well as his unique position in heaven at the right hand of the Father 1:13 (cf. Ps 110:1). At the end of the series of biblical quotations, the audience have no doubt; Jesus is the only Son of God who was chosen before the world began and was privileged with a unique position in God's presence.

Having heard that Jesus, superior over the angels, was the last word of God, the audience were encouraged to stay alert lest they would drift away (2:1-4). They were exhorted to pay attention to God's message of salvation spoken through his only Son and confirmed by those who heard him speaking. ${ }^{15}$ God himself confirmed the validity of this message by means of signs, marvels and miracles. The lack of heed to this message would be disastrous for the audience. Therefore, the author reminded the audience that disobedience would receive a just punishment (2:2).

Having exhorted the audience not to neglect the word of such great salvation, the author moved on and called to their mind that Jesus had accomplished redemption. In his death, all things were subject to him, for he tasted death on behalf of all. He is now crowned with glory and honor, and by God's grace his death benefits all humanity (2:5-9).

Since the audience experienced various difficulties in confessing to be Christian, the author reminded them that Christ, leader of their salvation, was also suffering for a while. In the author's own words, it was fitting to make perfect the one who brings many to salvation (2:10). Christ not only suffered for humanity, but he also proclaims God's name to all his brothers, the holy assembly

15 The reference to those who have heard him (Lord) speaking suggests that the audience witnessed neither Jesus' activity nor heard the apostles preaching. Therefore, it is correct to assume that the members of the audience are a second or third generation of Christians. They have to struggle with sluggishness, and the lack of enthusiasm in professing the Christian faith and everything that it entails. 
of the faithful, the children that God gave him (2:12-13). The immediate context that precedes Heb 3:1-6 is the statement that Christ the merciful and faithful high priest, shared the same human nature (2:17-18). The term "high priest" ( $\alpha \rho \chi 1 \varepsilon \rho \varepsilon u ́ \varsigma)$ in 2:17 serves as a transitional word connecting the previous section to the description of Jesus the "high priest" ( $\dot{\alpha} \rho \chi \varepsilon \rho \varepsilon ́ \alpha)$ and apostle of our confession in $3: 1 .^{16}$

\section{Chiasmus as the Rhetorical Device to Present the Superiority of Jesus ${ }^{17}$}

It has already been noted, Heb 3:1-6 is a central element in the first series of eleven units 1:1-5:10. These units form a chiastic structure wherein Heb 3:1-6, the description of Jesus as the Son faithful beyond Moses, serves as a turning point, the unparalleled element of the whole first part of the letter. Hebrews $3: 1-6$, the object of this study, unveils a chiastic structure which can be outlined as follows:

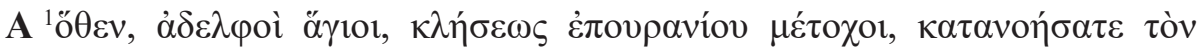

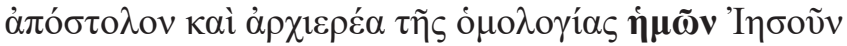

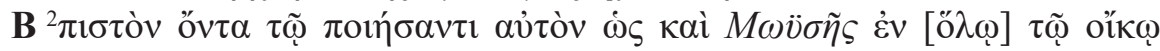

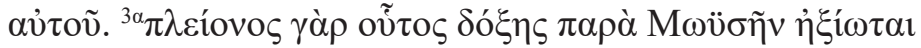

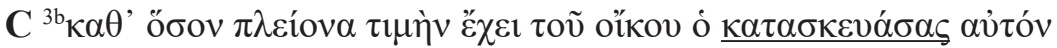

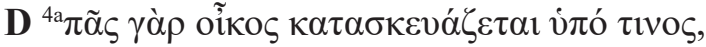

C' ${ }^{4 b}$ but ó $\delta \dot{\varepsilon} \pi \alpha ́ v \tau \alpha \underline{\kappa \alpha \tau \alpha \sigma \kappa \varepsilon v \alpha ́ \sigma \alpha \varsigma} \theta \varepsilon o ́ \varsigma$

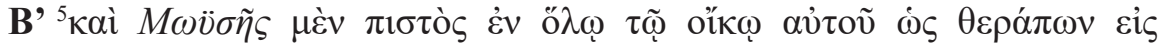

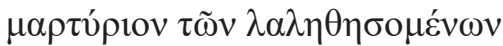

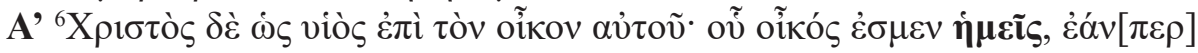

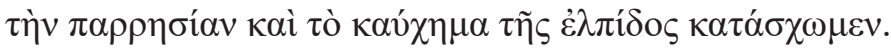

The main reasons to outline the passage in this way are as follows. The only occurrences of the personal pronoun i $\mu \varepsilon i \bar{\zeta}$ in verses 1 and 5 set them apart as the first set of parallel units. Secondly, the reference to Moses and to Num 12:7 sets verses 2 and 5 as a second set of parallel units. Thirdly, the only occurrence

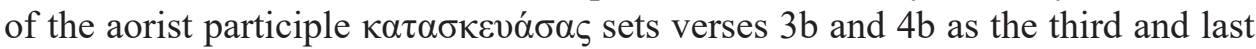
set of parallel units. Finally, the only unparalleled unit, verse $4 a$, is a pivot, a turning point of the whole section.

16 Heil, Hebrews, 87

17 The passage could be outlined in many different ways. It could be outlined on the basis of the grammar or on the basis of its content. I follow the structure proposed by Heil (Hebrews, 87-88). For the chiasm and other rhetorical devises used by the biblical authors, see J. Resseguie, Narrative Criticism of the New Testament. An Introduction (Grand Rapids, MI: Baker Academic 2005) 41-79. 


\section{Reader-Oriented Analysis of the Passage}

\subsection{Turn Your Attention (Heb 3:1)}

Therefore, holy brothers, partners of a heavenly calling, turn attention to the apostle and high priest of our confession, Jesus. The first unit opens with a particle ö $\theta \varepsilon v$. It serves to catch the attention of the audience and to make clear that what follows is a consequence of what has been said so far. The audience heard the same particle ö $\theta \varepsilon v$ in 2:17 where the idea of Jesus, the merciful and faithful high priest, was introduced for the first time. The audience are therefore invited to look at Jesus who is able to help those who suffer because he himself suffered $(2: 17-18) .{ }^{18}$

"Holy brothers" and "partners of heavenly calling" are two of the many titles that the author uses to address the audience. These two titles, used as a captatio benevolentiae, serve to catch the attention of the audience. ${ }^{19}$ At the same time, both one of them have a more specific function. The first title "holy broth-

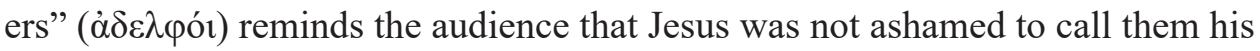
"brothers" (å $\delta \varepsilon \lambda \varphi o v ́ \varsigma)$. Furthermore, it reminds the audience that Jesus promised to proclaim and glorify God's name to his "brothers" ( $\left.\dot{\alpha} \delta \varepsilon \lambda \varphi \circ \tilde{i}_{\varsigma} \mu \mathrm{ov}\right)$ and in the midst of the assembly $(2: 11-12) .{ }^{20}$ Hearing that the proclamation of God's

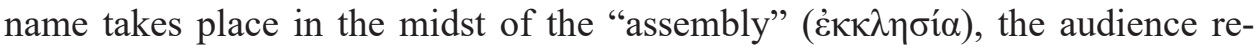
member some of the OT passages where the noun "assembly" occurred. They realize that the noun "assembly" (Deut 4:10; 9:10; 18:16) was frequently used in a liturgical context where the Torah was read. The noun referred also to a cultic practice of the $t \hat{d} d \hat{a}-\mathrm{a}$ ritual to thank God publicly for an intervention in the life of the community. ${ }^{21}$ This recollection of texts makes clear that they are called brothers, for they take part in a liturgical context where Christ proclaims God's name. Finally, the audience remember that Christ "was made similar to his broth-

18 Luke Timothy Johnson (Hebrews. A Commentary [NTL; Louisville, KY: Westminster John Knox 2006] 106) notes that the author continues to develop the previous idea, Jesus is the merciful and faithful priest, but at the same time, he marks a new sharp rhetoric turn. He picks up the language of "brothers" and those who are sanctified. William L. Lane (Hebrews 1-8, 75) interprets them in the same way. James Swetnam ("The Structure of Hebrews 1:1-3:6," 58) believes that Heb 3:1-6 is a key passage of the whole section Heb 1:1-3:6. The vocabulary clearly indicates that this passage looks back to what has been said so far about Jesus, the high priest.

19 P. Garuti, Alle origini dell'omiletica cristiana: La lettera agli Ebrei (SBFA 38; Jerusalem: Franciscan Printing Press 1994) 205. I believe that both titles, "holy brothers" and "partners of heavenly calling" are more than a simple captatio benevolentiae. These titles are not only a literary device that seeks to secure the goodwill, but describe the real state of the audience.

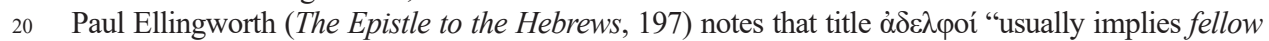
Christian not fellow Jews and refers to both male and female." It is evident that the letter is addressed to the whole congregation and not only to its leaders.

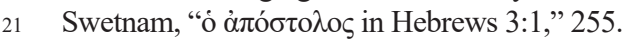




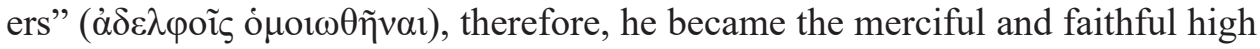
priest (2:17). It was Christ's participation in human nature that enabled him to expiate for the sins of the people (2:17).

This unique relationship between Jesus and the audience is further emphasized by the adjective "holy" (ö $\gamma 101)$. This small and apparently insignificant adjective plays a very important role in the unit. The audience keep in mind that Jesus (2:11) was identified as "one who sanctifies" ( $\dot{\alpha} \gamma(\alpha \dot{\zeta} \omega v)$ and therefore he is the only "one who makes them holy" ( $\dot{\alpha} \gamma 1 \alpha \zeta o$ ó $\varepsilon v o r)$. The audience realize that Jesus makes them perfect for heavenly worship. In this way, the audience are encouraged to respond to the title "holy" by conducting a way that lives up to the name that they now bear.

The second title "partners of a heavenly calling," the audience understand in two complementary ways. The heavenly calling is a call from God and a call to God. ${ }^{22}$ It is clear that the heavenly calling comes from God, for he spoke in many different ways, and now he speaks through his Son (1:1). It is important to

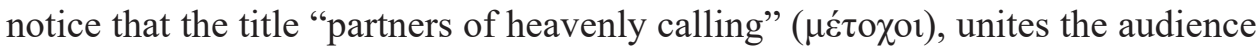

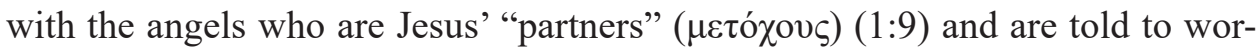
ship Jesus as he enters the world (1:6). ${ }^{23}$ The audience have to listen to the voice spoken through the Son, letting Jesus sanctify them and so enter into heavenly worship. ${ }^{24}$ In other words, they have to become involved in the worship just like the angels (1:14). The title "partners of heavenly calling" is an invitation because the noun "calling" ( $\kappa \lambda \tilde{\eta} \sigma \mathrm{\varsigma})$ implies primarily the idea of an invitation to the experience of a special privilege and responsibility. Thus, the audience are called to have a share in the heavenly worship as well as share in Jesus' life in heaven

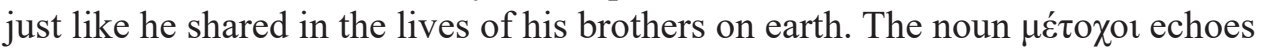
Christ's "participation" ( $\mu \varepsilon \tau \varepsilon \dot{\sigma} \sigma \varepsilon v)$ in human flesh and blood (2:14). ${ }^{25}$

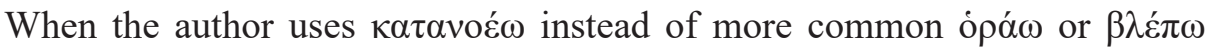
and invites them to turn their attention to Jesus, he makes clear that the audience should not merely see or perceive Jesus. ${ }^{26}$ The audience have to turn their

22 W. Barclay, The Letter to the Hebrews (Louisville, KY: Westminster John Knox 2002) 35; A.C. Mitchell, Hebrews (SP 13; Collegeville, MN: Liturgical Press 2007) 80; Casalini, Agli Ebrei, 137; Ellingworth (The Epistle to the Hebrews, 198) notes that commentators are divided. Some choose to read heavenly calling as call from heaven while others as call to heaven.

23 Heil, Hebrews, 88.

24 Thomas K. Oberholtzer ("The Warning Passages in Hebrews. Part 2: The Kingdom Rest in Hebrews 3:1-4:13," BSac 145 [1988] 186) notes "the use of these terms (ö $\gamma 10 t$ and $\mu \dot{\varepsilon} \tau o \chi 01)$ indicates that the author of Hebrews viewed his readers as regenerate."

25 Mitchell, Hebrews, 80.

26 Both verbs (ópó $\omega$ or $\beta \lambda \varepsilon ́ \pi \omega)$ have been previously used by the author (2:8-9). The use of a rare verb must have been intentional, therefore, it cannot be neglected or understood as a simple synonym. The au-

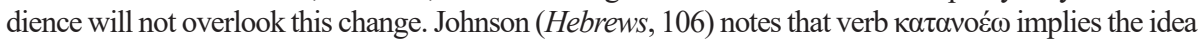
to look at in order to learn something. Erich Grässer (An die Hebräer, 162) maintains that this verb is the most important verb of the unit. Paulo Garuti (Alle origini dell'omiletica cristiana, 246) agrees. 
attention to Jesus in a reflective manner. They have to consider him carefully, his position and what he did. If the audience contemplate or fix their look on Jesus, they will be preserved, and will not drift away (2:1). A careful and contemplative manner of looking serves as a pause for the audience to consider what it means that Jesus is the apostle and the high priest of our confession. Since a single article ( $\tau$ óv) unites both titles, apostle and high priest, they probably form a coherent union in the mind of the author. ${ }^{27}$ The audience reminisce that Jesus was identified as the merciful and faithful high priest $(2: 17)$. However, the term "apostle"

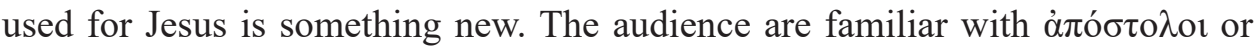
those who heard Jesus speaking (2:3), but the current use of the term and its application to Jesus is a novelty. ${ }^{28}$

Although the usage of the title "apostle" is new, the audience are familiar with the idea of Jesus as the messenger of God, an envoy who proclaims His message. At the beginning of the letter, the author informed the audience that God spoke in many different ways but now he speaks through his Son (1:1). In this way, the author informed the audience that the Son was the last envoy who came to deliver God's message. The audience also realize that the noun "apostle" echoes the cognate verb "to send" ( $\dot{\alpha} \pi \circ \sigma \tau \dot{\varepsilon} \lambda \lambda \omega)$. The angels became ministering spirits

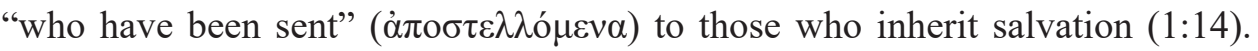
Finally, the audience remembers that Jesus proclaims God's name to his brothers and, in the midst of the assembly, praises God (2:12). Based on the previous context, the audience understand that Jesus is truly God's apostle, his messenger and envoy who was entrusted to deliver a final message.

At the same time the audience are told that Jesus' mission was not only to proclaim God's will. He was also appointed to be the high priest of our confession. The audience understand that the first and primary task of any priest is to present offerings, petitions and prayers on behalf of the people. From this perspective, it becomes clear as to why the author chose to combine these two titles by a single article. Jesus is the apostle, for he was sent by God to proclaim the word of God.

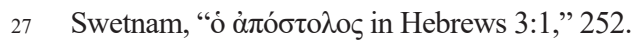

28 Although it is possible to assume that the author and his audience knew at least some of the traditions of the Gospel, it is harder to prove that they were familiar with the Gospel of John and its presentation of Jesus as the one who was sent by God 3:17, 34; 5:36; 6:29, 57 ( $\dot{\pi} \pi \dot{\varepsilon} \sigma \tau \varepsilon 1 \lambda \varepsilon v)$. Lane (Hebrews 1-8, 75-76) notes that the title "apostle" might be an allusion to the Jewish sources where the high priest is presented as šlyh. The Greek translation of the term would be áлó $\sigma \tau 0 \lambda$ os. The title "apostle" might also be an allusion to Moses who was sent to Pharaoh (Exod 3:10). In this

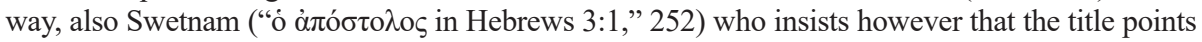
to Christ's mission to proclaim God's name. Since the audience have to understand fully the meaning of the title, I believe that the meaning of the title "apostle" has to be culled from the previous context. 
At the same time, he is the high priest whose primary task is to intercede or to respond from the side of humans to God. ${ }^{29}$

The audience are to appreciate the two aspects of Christian worship, proclaiming God's word and sanctifying all those who contemplate Jesus. Both aspects have Jesus as the forerunner or initiator of the Christian worship. ${ }^{30}$ Jesus is an apostle because he proclaims God's word. He is also a high priest, for he sanctifies his brothers, partners of heavenly calling.

\subsection{Faithful beyond Moses (Heb 3:2-3a)}

Being faithful to the one who made him, as also Moses in all his house. ${ }^{3 a}$ For this one has been considered worthy of greater glory beyond Moses. The idea of Jesus as the high priest and apostle of our confession is further developed in the second element (B) of the chiastic structure. Here Jesus is described as the one who is faithful to the one who made him. Hearing the present participle "being" (öv $\tau \alpha$ ), the audience understand that Jesus' faithfulness has a lasting character. Jesus' faithfulness is not the first occurrence of the term in the letter. In the first case (2:17), Jesus' faithfulness was described in relation to the people. He was presented as the merciful and faithful high priest before God to expiate the sins of

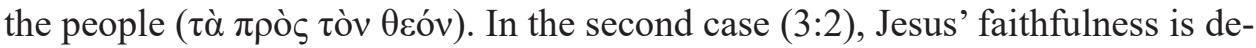
scribed in relation to God. He is presented as the one who is faithful "to the one

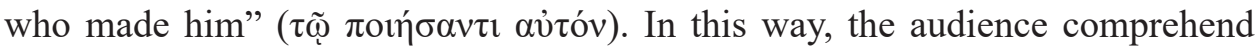
why Jesus is able to come and help them. He helps the audience because he suffered for them. He is faithful so he may expiate for their sins.

At this point the audience have to decipher the exact meaning of the aorist participle $\pi$ oví $\sigma \alpha v \tau t$. The previous context suggests that creation is meant. In fact, the audience heard the verb $\pi$ oté $\omega$ in the sense of creating $(1: 2,7) .{ }^{31}$ The scriptural quotation — this day I have begotten you (1:5) —also suggests that a creation of the Son is meant. Since the audience heard that God chose to speak now in the person of his Son, they recognize the aorist participle $\pi$ oví $\sigma \alpha v \tau t$ as a reference to Jesus' appointment to be God's final messenger to the people, and as the high priest of the heavenly worship. ${ }^{32}$

29 The idea was proposed by William Barclay (The Letter to the Hebrews, 36-37) and is still followed. Lane (Hebrews 1-8,75) notes that these two titles are combined for they "simply sum up the presentation of Jesus in 1:1-2:18."

30 Lane (Hebrews 1-8, 76) notes "Jesus is characterized neither by the word alone nor by the priestly office alone, but by both in conjunction." Alan C. Mitchell (Hebrews, 81) interprets in the same way.

31 Mitchell (Hebrews, 81) notes "some commentators opt for the meaning make, which suggests that Jesus was faithful to God, who created him." In this same way Grässer, An die Hebräer, 165; Johnson, Hebrews, 107; Casalini, Agli Ebrei, 138.

32 Heil, Hebrews, 89. 
The author uses the subordinating comparative conjunction "as" ( $\dot{\omega} \varsigma)$ to set the relationship between Jesus' mission as the high priest and apostle of our confession, and Moses (3:2). In this way, both are presented as equal; both are faithful. ${ }^{33}$ Hearing the name Moses, the audience immediately recall the biblical traditions linked to him. First of all, the audience recognize that the reference to Moses echoes some OT passages. ${ }^{34}$ Numbers 12:7 presents Moses in contrast to Aaron and Miriam. According to this text, Moses was faithful in all his house. Even though the immediate context of Num 12:7 suggests that the comparison in the Pentateuch was limited to the closest house, namely, the family of Moses, it can also refer to a larger, more generic group. ${ }^{35}$ In this way, the audience understand the noun "house" as a reference to the entire wilderness generation, and then by extension, to the chosen people of God.

Having learned of Jesus' faithfulness, the audience hear a further development. The explanatory subordinating conjunction "for" ( $\gamma \alpha \dot{\alpha} \rho)$ introduces a clause that explains why the author invites the audience to turn their attention to Jesus (3:3a). The author explicitly identifies Jesus as worthy of greater "glory" ( $\delta$ ó $\xi\rceil \varsigma)$ than Moses. The comparison between Jesus and Moses moves from equality to superiority. The audience recall that Moses asked to see God's "glory" ( $\delta$ ' $\xi \alpha v)$ and was actually allowed to see it under certain conditions (Exod 33:18, 22). These two passages suffice to perceive that there was a unique relationship between God and his faithful Moses. He was the only one to whom God spoke face to face and not in riddles (Exod 12:8).

The unheard of and unprecedented uniqueness of the relationship between God and Moses does not obscure the main point of the explanatory clause. The passages pertaining to Moses and to the glory of God enable the audience to understand fully why Jesus is worthy of a greater glory. Moses was only allowed to

33 James W. Thompson (Hebrews, 79) notes that Jesus' faithfulness demands the faithful response of the people.

34 Lane (Hebrews 1-8,75), contrary to many contemporary commentators, suggest that in verse 2 the au-

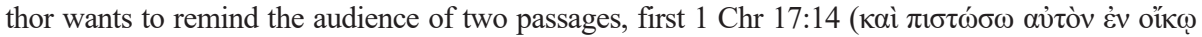

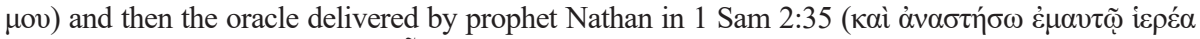

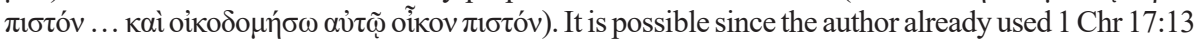
in 1:5b. Moreover, the verb $\pi \imath \tau \tau$ co, which means make faithful or appoint, seems to fit better in the present context, where faithfulness and creation or appointment are considered. Although the idea proposed by Lane has its advantages, I believe that the author refers to Num 12:7. This text will be quoted again in verse 5 and sets these two verses as parallel units B and B'. In this way also Thompson, Hebrews, 81.

35 The noun "house" can be used in a few different senses. It can be used in the sense of a building or in the sense of a family or a household. It is frequently used to describe the universe, a dynasty or even the people of Israel. Craig R. Koester (Hebrews, 245) notes that a number of OT passages call the sanctuary or Tabernacle God's house (Exod 23:19; 34:26 $1 \mathrm{Kgs} \mathrm{6:1;8:20).} \mathrm{Since} \mathrm{it} \mathrm{is} \mathrm{impossible}$ to analyze all the occurrences and their variants, I chose to indicate only a few which refer to Israel guided by Moses in the wilderness Lev 10:6; Num 20:29. 
see God's glory, whereas Jesus is the refulgence of God's glory (1:3). Moreover,

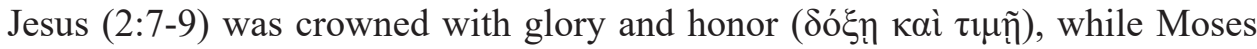
was only allowed to see God's glory ( $\delta$ ' $\xi \alpha v$ ).

When the audience hear the comparison between Moses and Jesus, they pay attention not only to the verbs and nouns but also to the prepositions. Thus, they are able to perceive an important train of thought. Jesus as the Son of God inherited a name which is superior or "beyond" ( $\pi \alpha \rho \alpha$ ) the name of the angels (1:4). God anointed his Son with the oil of gladness "beyond" ( $\pi \alpha \rho \alpha$ ) his partners who worship him (1:9). Therefore, he is considered worthy of greater glory "beyond" ( $\pi \alpha \rho \alpha$ ) Moses (3:3). Finally, the audience recall that Jesus and not Moses endured suffering for a while, in order to bring to "glory" ( $\delta$ ó $\xi \alpha v)$ many children of God (2:10).

Having realized the greatness of Jesus, far beyond Moses, the audience are ready to answer the heavenly calling. The audience will put their complete trust in Jesus who is both the apostle and high priest. He is faithful like Moses and worthy of greater glory beyond him. Hence, they will trust Jesus more than the exodus generation trusted and followed Moses with whom God spoke face to face. ${ }^{36}$

\subsection{Greater Honor Has the One Who Furnishes (Heb 3:3b)}

Just as greater honor than the house has the one who furnishes it. The correlative pronoun "just as" ( $\kappa \alpha \theta$ ' ö $\sigma \circ \varsigma)$ enables the author to continue the comparison between Jesus and Moses. Paraphrasing the author's words, an artisan is far superior to his work. By analogy, any work, although inferior, points to a greater mind that envisioned and fashioned it. ${ }^{37}$ In this comparison, the attention of the audience is drawn to the greater honor of the one who furnishes the house. The author continues the previous thought and further demonstrates the superiority of Jesus' glory and honor.

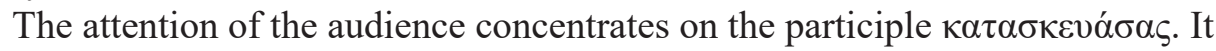
is not entirely clear whether it has to be understood as "one who brings a structure into being," namely builds it, or as "one who makes it ready," namely furnishes

36 Thompson (Hebrews, 80) notes "the place of Moses in Jewish literature also indicates why he is the natural object of comparison. In the OT, he is the giver of the law, a member of the tribe of Levi (Exod 2:1-4), and a priest (Ps 99:6) who serves at the altar (Exod 24:4-8). He is especially glorified in the intertestamental age."

37 Harold W. Attridge (The Epistle to the Hebrews, 110) notes a very close parallel between the image used by the author of Hebrews and one used by Philo. This similarity led some commentators to assume that the author of Hebrews was influenced by Philo and his works. Although this possibility cannot be completely excluded, it is safer to assume that both, Philo and the author of Hebrews, used a universally known truth. 
it. Since the result of the activity has to point to a greater honor of the one who

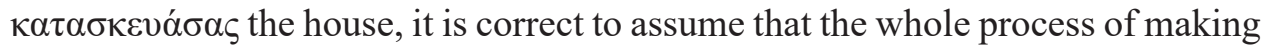
the house ready is considered by the audience. This process includes both, building a structure and preparing it to function in all its aspects.

In order to specify what the author has in mind-building or furnishingthe audience recall some OT passages. First of all, the audience recall Num 21:27

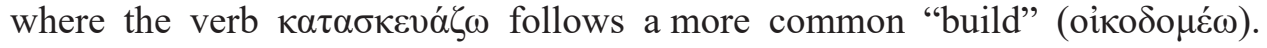

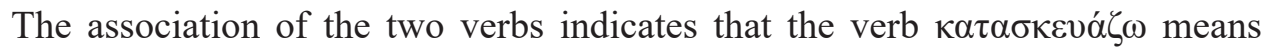
more than a simple construction. ${ }^{38}$ Next, a well-known passage from Wisdom 9:2

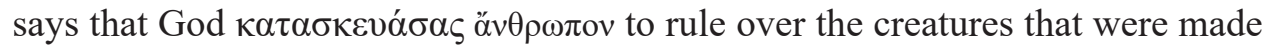
$\left(\gamma \varepsilon v o \mu \varepsilon v^{\prime} \omega v\right)$ by him. Also, in this case the association of the two verbs specifies

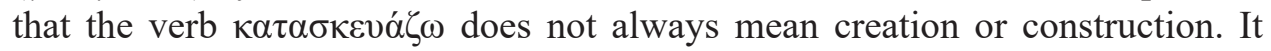
can also be taken in the sense of preparation or furnishing.

\subsection{Every House is Furnished by Someone (Heb 3:4a)}

For every house is furnished by someone. The explanatory subordinating conjunction "for" ( $\gamma \alpha \dot{\alpha} \rho)$ indicates that the author continues to explain the superiority of Jesus' glory. In order to further develop the existing idea, the author calls to mind a common experience of daily life. A generic statement that the builder is worthy of greater glory than a house itself is again brought to attention and is further generalized. Thus, the audience recall what is commonly known, and admit

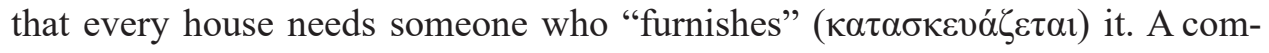
mon experience assures the audience that making a house ready, that is building and furnishing it, requires someone who is able to do so. At this point the audience eagerly await the disclosure of who furnishes this house. The attention of the audience reaches its climax in this unparalleled unit D.

\subsection{Only God Furnishes All (Heb 3:4b)}

But the one who furnishes all things is God. Having heard an unparalleled unitevery house is furnished by someone-the audience experience a pivot and hear

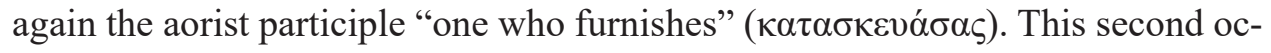
currence of the participle is not a mere repetition of the previously stated idea, but a further development.

38 There are a few more passages like this one. Since it is impossible to list them all, I chose only a few. I believe that these examples fit well to illustrate the pattern. "He strengthened ( $\alpha \alpha \tau^{\prime} \sigma \chi 0 \sigma \varepsilon v$ )

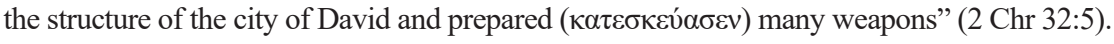


Repeating the participle, exactly in the same form as it was in the parallel unit $\mathrm{C}$, the author specifies that the someone who furnishes all things is God. In this way, the audience find the first important answer. God is the first cause of all. Hearing that God furnishes all things, they remember that God created all things through his Son (1:2). Secondly, they recall a series of OT quotations that assign to Christ a role in creation (1:10). Thirdly, they call to mind that the first occurrence of the aorist participle $\kappa \alpha \tau \alpha \sigma \kappa \varepsilon v \alpha$ ó $\sigma \varsigma$ s was used to further demonstrate the superiority of Jesus' glory and honor. In this way, once again the audience are told that creation is a work of the Father together with his Son who is considered worthy of a greater glory.

Jesus' glory is superior not only because he is crowned with glory, but also because he, along with God the Father, is the only one who furnishes the house. At this point, the audience realize that since the first words of the letter, Jesus was presented as the object of heavenly worship (1:6). The angels were invited to worship him as he entered the world. Jesus also promised to proclaim God's name in the midst of the assembly ( $\dot{\varepsilon} \kappa \kappa \lambda \eta \sigma i ́ \alpha)$ which can denote a liturgical setting (2:12) as a celebration of tôda ${ }^{39}$ Furthermore, the audience have been sanctified by Jesus who made them perfect for heavenly worship (1:10) and expiated their sins. Once made holy, the audience are called to be partners in heavenly worship (3:1) along with the angels who worship the Son (1:9). At this point, they grasp that God not only builds and furnishes the house for worship, but also provides everything that is needed for this worship and enables them to take part in this worship.

\subsection{Moses Was Faithful in All His House (Heb 3:5)}

And Moses was faithful in all his house as a servant for testimony of what would be spoken. Having heard that God is the only one who furnishes the house, the audience now experience a further progress and development. The author quotes Num 12:7. The audience remember that the same quotation has been recalled in a parallel unit B (3:2-3a). This creates a parallel progression of thought and the audience perceive it since the wording is almost the same. Once again,

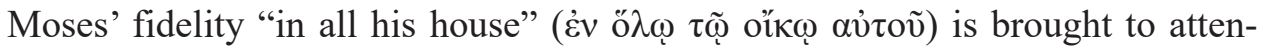
tion. The repetition of the biblical quotation should not be taken as a stylistic procedure aiming to provide a rhythm for the unit or to complete the void. On the contrary, this apparently meaningless repetition has a specific, well-intended

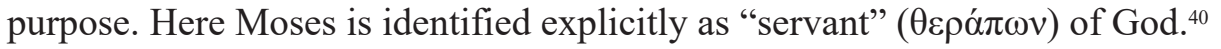

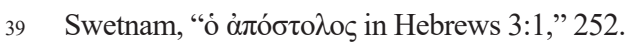

40 It is not easy to translate the Greek noun $\theta \varepsilon \rho \alpha ́ \pi \omega v$. The word is common in LXX but there is only one occurrence of the word in the NT. The two most common translations are "servant" and "attendant," but "helper" or "aid" are also possible. In order to translate this noun correctly, three things have to 
At first it is rather difficult to determine why this time the author chose to include in the quotation the title "servant." This appellative was omitted in the first occurrence of the same quotation (cf. 3:2). The correct answer to this puzzle most likely will have to remain unsolved. Unless, the title "servant" is intended to set a further contrast between Moses and Jesus. ${ }^{41}$ In this way a further element to compare Jesus and Moses is provided. ${ }^{42}$

So far, the audience heard a few times that Jesus is the Son of God. Jesus was begotten by the Father (1:5), all angels paid homage to him (1:6) for he sat at the right hand of his Father in heaven (1:13). Moses, although great and faithful more than anyone else in his house, was never called a son. Rather, he was called a "servant." The audience will not fail to perceive this difference. The title "servant" reminds the audience of a series of OT passages. Moses is called servant in Exod 4:10; 14:31; Num 11:11; Deut 3:24; Josh 1:2; 8:31. In all these passages, the noun "servant" is modified by the possessive pronoun "my" or by the noun God. This clearly indicates that the noun "servant" is a title of honor. Moses is not

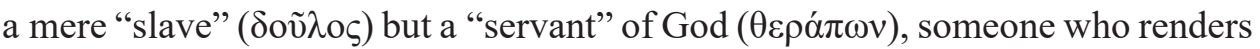
a devoted service. Since Moses rendered a devoted service to God, the usage of the term $\theta \varepsilon \rho \alpha \dot{\pi} \omega \omega v$ suggests a theological and not a social aspect. ${ }^{43}$

Again, the role of Moses is at the center of attention. The audience hear that Moses was faithful as a servant for testimony of the things that would be spoken. It is the first and the only time in Hebrews that the author uses the noun "testimony" ( $\mu \alpha \rho \tau$ vóvov). Although it is the first occurrence of the term, the audience are aware that the term was frequently used to designate something that would serve as a reminder for the generations to come. For a Christian audience, this term assumes a special meaning. In early Christianity, it was the group of the apostles who gave testimony to Christ's resurrection.

In the present context, the noun "testimony" echoes two cognate verbs. First of all, the "testimony" ( $\mu \alpha \rho \tau u$ prov) given by Moses reminds the audience that God "additionally testified" ( $\sigma v v \varepsilon \pi \mu \alpha \rho \tau \nu \rho o \tilde{v} \tau \tau \varsigma \varsigma)$ to the veracity of the salvation by signs, wonders, various acts of power, and the distribution of the gifts of

be taken into account. First, the Greek noun implies an idea of a devoted service. Second, Moses was $\theta \varepsilon \rho \alpha ́ x \omega v$ in all his house. This might suggest a public office. Third, the cognate verb $\theta \varepsilon \rho \alpha \pi \varepsilon v ́ \omega$ means to render service, homage or serve a divinity. Koester (Hebrews, 246) notes that participle $\theta \varepsilon \rho \alpha \pi \varepsilon v$ ov $\sigma \mathrm{v}$ is used for those who ministered in the temple. Herman W. Beyer (" $\theta \varepsilon \rho \alpha \pi \varepsilon v ́ \omega, "$ TDNT III, 128-32) notes that "common in the LXX, this word is used in the NT only for Moses in Heb. 3:5. The point is that Moses is a servant in contrast to Jesus the Son." For these reasons, I chose to translate the noun $\theta \varepsilon \rho \alpha ́ x \omega v$ as "servant." It implies the idea of a devoted service that is performed in public for a divinity. It also makes clearer the difference between Moses and Jesus.

41 The use of correlative $\mu \varepsilon^{\prime}$... $\delta \dot{\varepsilon}$ in 3:5-6 suggests that Moses, the servant in the house is compared to Christ, the Son over the house.

42 Thompson, Hebrews, 82.

43 Koester, Hebrews, 246. 
the Holy Spirit (2:4). Secondly, Moses' "testimony" ( $\mu \alpha \rho \tau$ róprov) echoes the fact that somebody "testified" ( $\delta 1 \varepsilon \mu \alpha \rho \tau u ́ \rho \alpha \tau o)$ in the Scripture (2:6). Based on these two previous occurrences, it is clear that the audience have to be mindful of the content of Moses' testimony. In fact, the testimony that will be given is not any word but a word of God as the divine passive "what would be spoken" $(\lambda \alpha \lambda \eta \theta \eta \sigma o \mu \varepsilon ́ v \omega v)$ implies.

Hearing the expression what would be spoken, the audience recall what they heard in the opening verses of the letter. The future passive form "what would be spoken" ( $\lambda \alpha \lambda \eta \theta \eta \sigma o \mu \varepsilon ́ v \omega v)$, echoes that at different moments in the past, God "spoke" ( $(\lambda \alpha \lambda \eta \dot{\sigma} \alpha \varsigma)$ to the ancestors through the prophets, but in the final days he has "spoken" ( $\dot{\varepsilon} \lambda \alpha \dot{\lambda} \eta \sigma \varepsilon v)$ in the person of his Son (1:1-2). Since the message "spoken" ( $\lambda \alpha \lambda \eta \theta \varepsilon i ́ \varsigma)$ by God through the holy angels was reliable, they will certainly not go unpunished, if they neglect such a great salvation "spoken" $(\lambda \alpha \lambda \varepsilon \tilde{i} \sigma \theta \alpha \imath)$ by the Lord (2:1-2). It seems that this last reference is very important for a correct understanding of the future participle $\lambda \alpha \lambda \eta \theta \eta \sigma o \mu \varepsilon \dot{v} \omega v$. In fact, here it is evident that "what would be spoken" refers to God's words spoken through his Son who was the last messenger. ${ }^{44}$

At this point the audience realize that Moses testified to God's message like no one else in his house. He was one of the many prophets through whom God spoke in the past (1:1) ${ }^{45}$ The audience conclude that Moses' testimony is comparable to those who heard Jesus speaking (2:3). The only, yet striking, difference between the two witnesses, is the time. Moses testified before the final days, before Jesus' coming, while the apostles and the audience testified after his coming. ${ }^{46}$ Hearing that Moses gave testimony to Jesus' coming before he actually came, encourages the audience to believe God and his message which he spoke through his Son. They are to imitate Moses' faithfulness for he bore witness to "what would be spoken." His testimony was not corroborated by signs, marvels and miracles (2:4). Finally, they are encouraged not to neglect such a great salvation, testified by Moses, the angels, and spoken through the Son.

\subsection{We Are House of God (Heb 3:6)}

But Christ as Son over his house, whose house are we, if to the boldness and to the boast of the hope we hold. Having explicated Moses' faithfulness and his witness to Jesus, the author moves on to exhort the audience in the last element

\footnotetext{
44 James Swetnam ("T $\tilde{\nu} \nu \alpha \lambda \eta \theta \eta \sigma o \mu \varepsilon ́ v \omega v$ in Hebrews 3:5," Bib 90 [2009] 93-100) argues that the future participle $\lambda \alpha \lambda \eta \theta \eta \sigma o \mu \varepsilon ́ v \omega v$ in Heb 3:5 "allude to the words of Christ at the institution of the Eucharist."

45 Schenck, Understanding the Book of Hebrews, 60.

46 Koester, Hebrews, 246.
} 
of the chiastic structure (A'). The only occurrence of the personal pronoun "we" (i $\mu \varepsilon \tilde{i} \varsigma)$ in 3:1 and 3:6 sets these two parallel units apart. At this point the audience are introduced for the first time to the title "Christ." Although it is the first occurrence of the noun, it is well known to the audience. They know that noun from the OT passages which relate to kings and prophets. In fact, according to the OT, prophets and kings were anointed so they could carry on the duties they have been called to do. In this way, the title "Christ" became a synonym for someone who held a leadership position.

Hearing the noun "Christ" (Xpıб宅), the audience recall that God "anointed" ('̌ $\chi \rho \imath \sigma \varepsilon ́ v)$ his Son with the oil of gladness as none of his rivals (1:9). This granted him an unprecedented position and enabled him to sit at God's right hand (1:13), to announce such a great salvation $(2: 3)$, and become perfect through his suffering (2:10). Jesus, being anointed, became the high priest of our confession who is able to expiate our sins and intercede for those who suffer (2:17-18). The anointing and appointment of Jesus is finally the main reason why the audience have to contemplate Jesus as the high priest and apostle of our confession $(3: 1){ }^{47}$

Having heard the title "Christ," the audience are reminded that Christ is faithful as Son "over" ( $\dot{\varepsilon} \pi i$ ) his house. The audience, being reminded twice that Moses was faithful "in" ( $\dot{\varepsilon} v)$ all his house, will not miss the mention that Christ is Son "over" ('ं $\pi$ í) his house. ${ }^{48}$ Based on the previous context, the audience understand that "house of God" is considered. ${ }^{49} \mathrm{He}$ in fact, is the only one who furnishes everything (3:4).

When the audience hear that Christ is "over the house" (oĩkov) as a Son, it re-

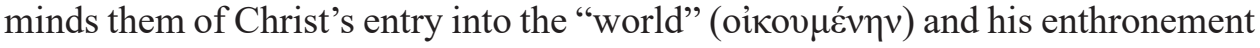
in heaven $(1: 6,8)$. They remember that he was begotten by God (1:5) to become the initiator of the salvation, and to bring many sons to glory (2:10). Since Christ entered into the inhabited world and is enthroned in heaven, that is, set over the house as a Son, it means that he brings into salvation those who belong to this house. And who belongs to this household? The author does not leave his audi-

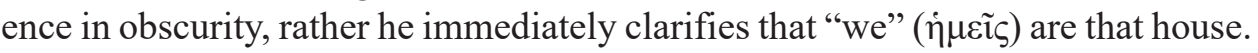

47 Koester (Hebrews, 247) notes: "here, as in Paul's letters, it (the title Christ) functions as a part of Jesus' name.” In the same way Mitchell, Hebrews, 83; Johnson, Hebrews, 110. However, it has to be noted that the previous context clearly indicates that the title Christ must have a deeper meaning. It should not be reduced to a simple idea of Jesus' surname. On the other hand, Attridge (The Epistle to the Hebrews, 111) is right when he notes that the title Christ "contrasts with Jesus used in the verse 1 , and so frames this periscope." But again, it is not a simple surname. The author might have used the same name Jesus, but since he chose a different one, which evokes what has been said so far, it was used for a certain reason.

48 According to Lane (Hebrews 1-8, 79), the function of the verse is to extend Jesus' superiority over Moses.

49 Hypothetically speaking, it is possible that the Greek relative pronoun oṽ might refer both to God and to Christ. That the "houses of God" and not "house of Christ" is meant is clear from the previous context where only "house of God" has been considered. Grässer, An die Hebräer, 168. 
Just as it happened previously in 2:1 and 3:1, the author identifies himself with the audience. This is evident by the use of the personal pronoun "we" (i $\mu \varepsilon i \bar{\varsigma})$. The audience does not fail to notice the personal involvement of the author. In fact, when the author invited the audience to look at Jesus (3:1), he acknowledged that Jesus is the high priest and apostle of "our" ( $\dot{\eta} \mu \tilde{\omega} v)$ confession. In the same way, he includes himself in the house ( $\dot{\eta} \mu \varepsilon \tilde{i} \varsigma)$. At this point, it becomes clear that Christ's position in the final unit A' recalls the two titles the audience heard in the opening unit A. Christ is set over the house of God in order to sanctify and call many brothers into heavenly worship. Those who accept this calling, and accept Christ's mission as the apostle, are sanctified and can be considered the household of God governed by Christ (3:6).

In the final part of the unit, the audience are reminded that being a house of God, is not unconditional. The audience are house of God. This means that they are part of the worshiping assembly in which Jesus is the apostle proclaiming God's name (2:12) and the high priest sanctifying his brothers $(2: 10) \cdot{ }^{50}$ When the audience hear the verb "to hold" ( $\kappa \alpha \tau \dot{\varepsilon} \chi \omega)$, they realize that their "holding" cannot be an unsteady one but a decisive as the verb implies. They have to re-

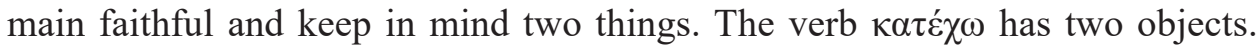
The first object is "boldness." The Greek noun for "boldness" ( $\pi \alpha \rho \rho \eta \sigma i ́ \alpha)$ includes the internal "disposition of confidence" and the external "expression of clear and public speaking." Boldness is fitting for free people and not for slaves. ${ }^{51}$ Since Jesus released the audience from slavery $(2: 15)$, they realize that through him, they have an assurance of a free, liberal approach to God. Moreover, they are also able to speak frankly, confidently and openly in public. In this way, it becomes clear for the audience that "drifting away" $(2: 1)$ or "neglecting the words of such a great salvation" (2:3) contradicts the liberty merited by Jesus. In other words, the audience become truly "house of God" if they hold fast, that is, if they contemplate Jesus, the faithful high priest and apostle of their confession who made them free.

Having explained that boldness is a very important aspect of Christian identity, the author does not stop here, but continues his exposition and introduces the second object of the verb "to hold." This object is "boast of the hope." So far,

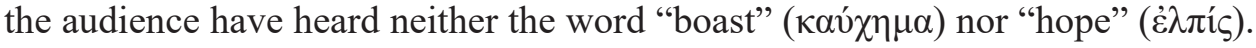
Although both terms are new, the audience will not have difficulty in understanding what the author means by "boast of hope." Since the author does not provide any indication, how the terms have to be interpreted, the terms can be

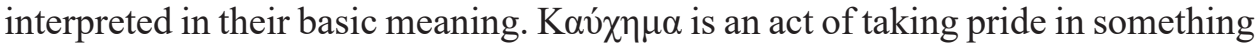
or someone that constitutes a source of pride. The audience are therefore encour-

50 Oberholtzer, "The Warning Passages in Hebrews. Part 2," 186.

51 Koester, Hebrews, 247. 
aged to be proud both openly and publicly. In the same way, the noun "hope" ( $\dot{\varepsilon} \lambda \pi i \varsigma)$ denotes the idea of looking forward to something with some reason for confidence or expecting fulfillment. The audience have therefore to look forward confidently. They must hold firmly, without hesitation.

What is the source of their pride and what are they looking forward confidently? The answer to these two questions is found in what the audience heard so far. Since the expression - boast of the hope-is found in the last element of the chiastic structure (A'), it is appropriate to look in the first parallel element (A) in order to decipher what is the source and to what they look forward. The content of the first parallel unit A clearly indicates that the reason for their "boast of the hope" is Jesus Christ who inherited their salvation (1:14).$^{52}$ All the audience have to do is to contemplate Jesus and proudly confess their faith. Now the audience finally understand that they can approach God in boldness. They can in boldness profess their faith, because they hold fast to their hope that is Jesus Christ. Being "house of God," and part of the worshiping assembly requires holding fast to Christ and to profess faith in him. ${ }^{53}$

\section{Summary Statement}

Having reached the end of the endeavor which was proposed at the beginning of this paper, it is time to gather the fruits of this research. A short analysis of the context has shown a special interest of the author in the role of Jesus and his superiority. He is the last word spoken by the Father, and he has been made perfect in order to sanctify his brothers. He is finally the merciful and faithful high priest who is able to help others who are being put to the test.

Having established Jesus' superiority over the angels, and having declared his ability to save, the author moved on to compare Jesus with Moses. The comparison was accomplished in two ways. Initially, the author was interested in reminding the audience that Jesus was as faithful as Moses. Then, he moved on to illustrate that Jesus is superior to Moses. This presentation proceeded in two ways; based on a biblical quotation and on the experience of daily life. At the end of the presentation, the audience realize that Jesus' superiority derives from many factors. First, Jesus is superior to Moses for he was considered worthy of a greater glory. Secondly, Jesus is superior to Moses for the furnisher of the house is worthy of a greater glory than the house itself. Thirdly, Jesus is superior to Moses for he is the Son of God, whereas Moses is only a servant of God. Finally, Jesus is

52 Johnson, Hebrews, 110; Grässer, An die Hebräer, 163.

53 Manzi, "La figura di Mosè," 13-14. 
superior since Moses only witnessed to what would be spoken later, he witnessed to Jesus' coming.

In the course of the exposition, the author describes the audience as holy brothers, partners of heavenly calling and house of God. All these titles serve as markers or catch words that capture the attention of the audience. At the same time, they are intended to make clear how great the new status of the audience is. They are brothers of Christ who has been made like them in order to bring them to salvation. God speaks to them and instructs them not to neglect the word of such a great salvation. The author uses two very important titles to describe Jesus Christ. He is high priest and apostle. Hearing these titles, the audience are reminded that God spoke through his Son who has been sent in order to sanctify them. Finally, these titles remind the audience that they have been called to take part in a heavenly worship where Christ is the apostle and high priest set over the house of God. The audience are to appreciate the two aspects of Jesus' mission among them-proclaiming God's will and sanctifying the audience.

\section{Bibliography}

Attridge, H.W., The Epistle to the Hebrew. A Commentary on the Epistle to the Hebrews (Hermeneia; Philadelphia, PA: Fortress 1998).

Barclay, W., The Letter to the Hebrews (Louisville, KY: Westminster John Knox 2002).

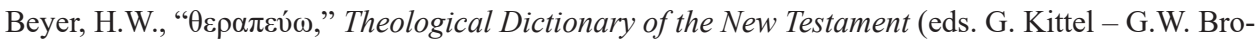
miley - G. Friedrich) (Grand Rapids, MI: Eerdmans 1965) III, 128-132.

Carter, W.C. - Hail, J.P., Matthew's Parables. Audience-Oriented Perspectives (Catholic Biblical Quarterly Monograph Series 30; Washington, D.C.: Catholic Biblical Association of America 1998).

Casalini, N., Agli Ebrei. Discorso di esortazione (Studium Biblicum Franciscanum Analecta 34; Jerusalem: Franciscan Printing Press 1992).

Casey, J., Hebrews (New Testament Message 18; Wilmington, DE: Glazier 1980).

Ellingworth, P., The Epistle to the Hebrews. A Commentary on the Greek Text (New International Greek Testament Commentary; Grand Rapids, MI: Eerdmans 1993).

Enns, P.E., "Creation and Re-Creation: Psalm 95 and its Interpretation in Hebrews 3:1-4:13," Westminster Theological Journal 55 (1993) 255-280.

Fowler, R.M., Let the Reader Understand. Reader-Response Criticism and the Gospel of Mark (Minneapolis, MN: Fortress 1991).

Garuti, P., Alle origini dell'omiletica Cristiana (Studium Biblicum Franciscanum Analecta 38; Jerusalem: Franciscan Printing Press 1994).

Grässer, E., An die Hebräer. Hebr 1-6 (Evangelisch-katholischer Kommentar zum Neuen Testament 17/1; Zürich: Benziger 1990).

Grässer, E., "Mose Und Jesus: Zur Auslegung von Hebr 3:1-6," Zeitschrift für die neutestamentliche Wissenschaft und die Kunde der älteren Kirche 75 (1984) 2-23. 
Heil, J.P., Hebrews. Chiastic Structures and Audience Response (Catholic Biblical Quarterly Monograph Series 46; Washington, D.C.: Catholic Biblical Association 2010).

Johnson, L.T., Hebrews. A Commentary (New Testament Library; Louisville, KY: Westminster John Knox 2006).

Koester, C.R., Hebrews. A New Translation with Introduction and Commentary (Anchor Bible 36; New York: Doubleday 2001).

Lane, W.L., Hebrews 1-8 (World Biblical Commentary 47a; Dallas, TX: Word Books 1991).

Manzi, F., "La figura di Mosè nell'epistola agli Ebrei e nel Dialogo con Trifone," Rivista Biblica 51 (2003) 3-55.

McKnight, E.V., Postmodern Use of the Bible. The Emergence of Reader-Oriented Criticism (Nashville, TN: Abingdon 1988).

Mitchell, A.C., Hebrews (Sacra Pagina 13; Collegeville, MN: Liturgical Press 2007).

Oberholtzer, T.K., "The Warning Passages in Hebrews. Part 2: The Kingdom Rest in Hebrews 3:1-4:13," Bibliotheca Sacra 145 (1988) 185-196.

Powell, M.A. What is Narrative Criticism? (Minneapolis, MN: Fortress 1990).

Rabinowitz, P.J., "Whirl Without End: Audience-Oriented Criticism," Contemporary Literary Theory (ed. G.D. Atkins) (Amherst, MA: University of Massachusetts Press 1989) 81-100.

Resseguie, J., Narrative Criticism of the New Testament. An Introduction (Grand Rapids, MI: Baker Academic 2005).

Schenck, K.L., Understanding the Book of Hebrews. The Story Behind the Sermon (Louisville, KY: Westminster John Knox 2003).

Scott, B.R., "Jesus' Superiority over Moses in Hebrews 3:1-6," Bibliotheca Sacra 155 (1998) 201-210.

Swetnam, J., "The Structure of Hebrews 1:1-3:6," Melita Theologica 43 (1992) 58-66.

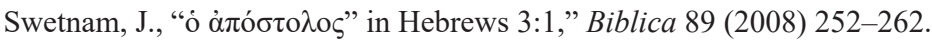

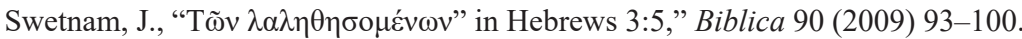

Thompson, J.W., Hebrews (Paideia Commentaries on the New Testament; Grand Rapids, MI: Baker 2008).

Tompkins, J.P., Reader-Response Criticism. From Formalism to Post-Structuralism (Baltimore, MD: Johns Hopkins University 1980).

Vanhoye, A., La structure littéraire de L’Épître Aux Hébreux (Paris: Desclée De Brouwer 1976). 